\title{
Persepsi Siswi Perempuan terhadap Perilaku Seks Bebas
}

\author{
Elin Eria Putri ${ }^{1}$, Dosi Juliawati ${ }^{2}$, Hengki Yandri ${ }^{3}$ \\ 1,2,3 Institut Agama Islam Negeri Kerinci \\ *Corresponding author, e-mail: elineriaputri25@gmail.com
}

\begin{abstract}
Today's teenage promiscuity is so concerning that some have casual sex. So the purpose of this study is to uncover the perception of female students of free sex behavior. This research method is quantitatively descriptive with the research population of all students of State Junior High School 24 Kerinci with the research subjects of all female students in class VII and VIII which amounted to 39 people. The data was revealed using the Free Sex Behavior scale, then processed descriptively. The results of this study revealed that female students perceive free sex behavior is a bad thing to do meaning that the average student has a perception with a good category. For that, it is recommended to the next researcher to research with a wider scale of research subjects.
\end{abstract}

Keyword: Perception, Students, Free Sex

\section{Pendahuluan}

Remaja yang dalam bahasa aslinya disebut adolescence, berasal dari bahasa latin adolescere yang (kata bendanya, adolescentia yang berarti remaja) yang berarti "tumbuh" atau "tumbuh menjadi dewasa". Dalam bahasa inggris murahaqoh yaitu adolescence yang berarti at-tadarruj (berangsur-angsur). Jadi artinya berangsur-angsur dalam menuju kematangan fisik, akal, kewajiban dan sosial serta emosional (Al-Mighwar, 2011). Adapun dalam Islam, secara etimologi, kalimat remaja berasal dari murahaqoh, kata kerjanya adalah raabaqo yang berarti al-iqtirab (dekat). Jadi secara etimologi, berarti mendekati kematangan secara fisik, akal, dan jiwa serta sosial. Hal ini dapat dikatakan mengisyaratkan pada hakikat umum, yaitu bahwa pertumbuhan tidak berpindah dari satu fase ke fase lainya secara tiba-tiba, tetapi pertumbuhan itu berlangsung setahap demi setahap (Al-Mighwar, 2011; Yandri, \& Juliawati, 2018)

Masa remaja merupakan salah satu periode dari perkembangan manusia yang ditandai dengan adanya perubahan-perubahan dari anak-anak menjadi dewasa yang termasuk dalam kelompok ini adalah anak yang berusia 13-25 tahun. Sedangkan menurut World Health Organization (WHO), remaja merupakan individu yang sedang mengalami peralihan yang secara berangsur-angsur mencapai pematangan seksual, mengalami perubahan seksual, mangalami perubahan jiwa, dari jiwa anak-anak menjadi dewasa, keadaan dari ketergantungan menjadi relative mandiri. Dalam masa peralihan menuju kedewasaan remaja sering memperoleh masalah seksual remaja yang tentu akan memberikan dampak terhadap kehidupan mereka. Hal ini disebabkan karena minimnya pengetahuan remaja sekarang tentang seks (Sari, 2011).

Sesuai dengan masa remaja yang mempunyai rentangan usia 11-25 tahun, masa remaja merupakan masa transisi dari masa kanak-kanak menuju ke masa dewasa. Selain mengalami perubahan fisik terdapat pula perubahan psikologis yang hampir universal, seperti: meningginya emosi, minat, peran, pola perilaku, nilai-nilai yang dianut, dan bersifat ambivalen terhadap setiap perubahan (Wahareni, 2006). Perubahan fisik yang cepat dan aktivitas hormon seksual kemudian menimbulkan perubahan-perubahan psikis maupun sosial. Dengan perkembangan kognisi dan 
emosi-emosi yang menyertai perkembangan fisik seksual, secara psikologis remaja mulai merasakan individualitasnya, menyadari perbedaannya dari jenis kelamin yang lain, merasakan keterpisahanketerasingan dari dunia kanak-kanak yang baru saja dilaluinya, namun juga masih asing dengan dunianya. Dalam kondisi ini mereka mulai mempertanyakan identitasnya.

Remaja berusaha menemukan jawaban atas kekaburan identitas itu melalui kelompok sosial di luar keluarga, yaitu kelompok teman sebaya (peer group). Teman sebaya memainkan peranan yang penting dalam perkembangan psikologis dan sosial sebagian besar remaja. Hal ini karena remaja tidak mengetahui cara bergaul dengan kawan-kawan dan orang dewasa lainnya, dan cara-cara yang dibutuhkan untuk menarik hati kawan-kawannya. Kelompok inilah yang merupakan bagian integral dari identitas sosial individu. Dengan interaksi tersebut memberikan kesempatan pada remaja untuk belajar bagaimana mengendalikan perilaku sosial, mengembangkan minat yang sesuai dengan usia, dan berbagi masalah dan perasaan bersama. Pada masa ini remaja cenderung konform dan mengikuti sikap atau perilaku kelompoknya. Bersama kelompoknya, remaja merasa menemukan "identitas" dan berharap tidak mengalami penolakkan dengan konformitasnya tersebut (Wahareni, 2006; Sartika \& Yandri, 2019).

Secara alami setiap remaja menerima tugas untuk menemukan identitas diri masing-masing, agar selanjutnya dapat memasuki masa dewasa secara sehat dan matang. Untuk itu mereka harus bergerak menuju orang lain (Wahareni, 2006). Di samping masuk dalam interaksi sosial yang semakin luas di luar keluarga, persoalan yang lebih penting adalah bahwa secara biologis mereka telah dibekali dengan kematangan organ-organ seksual untuk bergerak menuju individu lain yang berlawanan jenis (persoalan seks).

Pada masa remaja tidak sedikit remaja yang mengalami kegoncangan yang menyebabkan munculnya emosional yang belum stabil sehingga mudah melakukan pelanggaran terhadap normanorma dalam masyarakat. Pelanggaran tersebut bisa terjadi karena pengaruh lingkungan atau karena terlalu banyaknya larangan-larangan atau peraturan-peraturan yang harus dipatuhi oleh remaja. Sehingga mendorong remaja berusaha untuk mencari tahu dengan berbagai cara yang membuat mereka dengan begitu mudahnya terjerumus ke dalam penyimpangan-penyimpangan sosial terutama penyimpangan perilaku seks bebas (Aini, 2016). Adanya dorongan seksual yang timbul dapat dikendalikan remaja dengan cara mengalihkan pikiran yang positif, artinya tidak memikirkan hal yang dapat mendorong gairah seksualnya yang muncul (Istiqomah \& Notobroto, 2016).

Ketertarikan terhadap lawan jenis disertai dengan dorongan seksual merupakan hal yang begitu kodrat dialami oleh remaja. Remajapun mulai berkenalan, bergaul dengan teman-temannya yang berlawanan jenis, dan mengenal pacaran (Wahareni, 2006). Pandangan remaja terhadap seks kian berubah, remaja dengan sikap keserba bolehan, sebagian menganggap hubungan seks pranikah tidak perlu di persoalkan. Perilaku seksual dapat dikelompokkan menjadi empat kategori, yaitu berciuman, berpelukan, bercumbu (petting), dan berhubungan badan. Tidak jarang di kalangan remaja, mahasiswa sudah melakukan hubungan seks pranikah di hotel, kost, di rumah (dikala rumah dalam keadaan sepi), dan tidak jarang di tempat wisata terkadang juga di dalam mobil (Wahareni, 2006).

Perilaku seks bebas adalah perilaku yang didasari oleh dorongan seksual untuk mendapatkan kesenangan seksual dengan lawan jenis yang dilakukan tanpa ikatan pernikahan yang sah (Novitasari, Nikmah \& Sulistyoningtyas, 2017). Faktor - faktor yang mempengaruhi remaja 
perilaku seks bebas dari hasil penelitian Darmasih (Novitasari, Nikmah \& Sulistyoningtyas, 2017) menunjukkan bahwa faktor yang mempengaruhi perilaku seks bebas yaitu pengetahuan, pemahaman agama, Sumber Informasi, peran keluarga, dan persepsi yang tidak baik. dan juga terdapat hubungan lurus antara pengetahuan dan persepsi dengan informasi. Kurangnya pengetahuan, informasi tentang seks serta persepsi remaja mengenai seluk beluk seks yang salah merupakan salah satu indikator meningkatnya perilaku seks bebas di kalangan remaja (Susilawati, 2019).

Berdasarkan hasil observasi peneliti lakukan pada tanggal 30 Agustus 2018 di SMP N 24 Kerinci ada perbedaan persepsi siswa laki-laki dan siswa perempuan mengenai perilaku seks bebas. Dimana siswa laki-laki mempersepsikan bahwa perilaku seks bebas dikarenakan ingin menunjukkan bukti cinta nya, sama-sama mau, akibat nonton film pornografi, sedangkan siswa perempuan mempersepsikan bahwa perilaku seks bebas dikarenakan atas dasar cinta, takut kehilangan sehingga dia mau melakukan hal yang tidak baik, perilaku yang memalukan, perbuatan yang dilarang. Kemudian hasil penelitian Taufik pada tahun 2013 menunjukkan bahwa remaja yang mempersepsikan melakukan seks bebas, dikarenakan kurangnya mendapat kasih sayang dari orang tua, kurangnya iman tidak mengingat sang pencipta Allah SWT, rasa ingin tahu yang berlebih dan pergaulan bebas (Taufik, 2013). Merujuk pada Standar Kompetensi Kemandirian Peserta didik, dimana aspek perkembangan siswa adalah Landasan Perilaku Etis dengan tujuan siswa mengenal alasan perlunya mentaati aturan/norma berperilaku, dapat memahami keragaman aturan/patokan dalam berperilaku dalam konteks budaya, dan bertindak atas pertimbangan diri terhadap norma yang berlaku (Sugiyatno, 2019).

Waktu observasi yang peneliti lakukan kembali pada tanggal 11 Juli 2019 di SMP N 24 Kerinci, menunjukkan siswa laki-laki berpersepsi bahwa perilaku seks bebas karena ingin menunjukan bukti cintanya, sama-sama mau, akibat nonton film pornografi, sedangkan siswa perempuan mempersepsikan bahwa perilaku seks bebas dikarenakan atas dasar cinta takut kehilangan sehingga dia mau melakukan hal yang tidak baik, perilaku yang memalukan, perbuatan yang di larang. Kemudian dari hasil penelitian menunjukkan bahwa remaja mempersepsikan bahwa perilaku seks bebas itu hal yang tidak wajar karena merupakan perbuatan zina, karena kurangnya kasih sayang orang tua dan kurangnya pendidikan seks yang baik, dan ada yang juga mempersepsikan perilaku seks bebas hal yang wajar karena atas dasar rasa cinta (Novitasari, Nikmah \& Sulistyoningtyas, 2017). dan juga remaja mengatakan bahwa itu perilaku yang tidak senonoh, tidak patut ditiru, merusak martabat orang tua, memalukan, perilaku yang haram karena tidak sesuai dengan ajaran agama, mencemarkan nama baik sekolah maupun keluarga serta perilaku seks bebas di kalangan pelajar tersebut dapat memberikan contoh yang tidak baik bagi pelajar lainya (Taufik, 2013).

Kemudian menurut Pieter et al (Situmorang \& Sanusi, 2016) pada tahun 2011 yang mengutip pendapat Peplau dan beberapa para ahli ditemukan bahwa ada perbedaan perilaku seksual antara laki-laki dan perempuan dan hasil kesimpulannya menunjukkan bahwa Wanita cenderung pada kegairahan dan romantis sebagai integrasi seksual tertutup mengenai pengalaman seksual, cenderung malu-malu, konsevatif dan self-concious, Menekankan pada hubungan komitmen konteks seks. Lebih menekankan pada kultur, sosial dan situasional, Asosiasi seksnya pada cinta dan keintiman emosional. Sedangkan laki-laki cenderung kegairahan seksualnya secara indepedensi, agresi, bergairah, mencintai dan terbuka pengalaman seksual, cenderung pada kekuatan, terbuka 
dan moderat, menekankan pada kenikmatan fisik semata, lebih menekankan kekuatan dan akresivitas seksnya, asosiasinya seksnya pada ketertarikan kepuasan fisik

Di dalam Islam bahwa yang melakukan hubungan seksual yaitu setelah adanya ikatan pernikahan jika seseorang melakukan hubungan seksual tanpa adanya ikatan pernikahan dikatakan zina. Allah Swt berfirman dalam Al-Quran Surat Al-Isra' ayat 32 yang artinya: “Dan janganlah kamu mendekati zina, sesungguhnya zina itu adalah suatu perbuatan yang keji dan suatu jalan yang buruk". Ayat tersebut menjelaskan bahwa manusia dilarang untuk mendekati zina, karena zina itu merupakan suatu perbuatan yang keji. Diharapkan remaja menghindari berperilaku seks bebas dan lebih mendekatkan diri kepada Allah SWT, dengan seperti itu remaja akan bisa memilih mana yang baik atau yang buruk sehingga remaja bisa terhindar dari perilaku seks bebas. Sehingga di harapkan persepsi remaja tentang berperilaku seks bebas juga akan berubah.

Menurut Rakhmat (Marliany, 2010) persepsi adalah pengalaman dan objek - objek, peristiwa atau hubungan yang diperoleh dengan menyimpulkan informasi dan menafsirkan pesan. Dengan adanya informasi remaja tentang perilaku seks bebas yang baik akan mempengaruhi persepsi remaja terhadap perilaku seks bebas. Persepsi remaja tentang perilaku seks akan terbentuk melalui paparan pengetahuan yang mereka dapatkan baik dari sekolah, media sosial, orang tua maupun sumbersumber lainnya. Persepsi akan membentuk opini remaja tentang sesuatu hal yang diyakini dan selanjutnya dengan dukungan intensi atau niat akan direalisasikan dalam tindakan nyata. Bila persepsi remaja tentang perilaku seks positif berarti akan mempengaruhi niat remaja untuk tidak melakukan perilaku seks (Sumiatin, Purwanto \& Ningsih, 2017). Dimana menurut Kartono sifat remaja laki-laki lebih terbuka terhadap dorongan seksual, memiliki fantasi erotik yang agresif, pernah mengalami organisme dan tahu bagaimana menggunakan organ seks mereka, sedangkan sifat remaja perempuan penuh dengan keragua-raguan, ketidak pastian emosi, konflik batin, rela mengorbankan segala sesuatu untuk orang yang dicintainya, membutuhkan kemesraan dan mudah diransang dengan sentuhan dari lawan jenisnya (Astriani, 2007; Kholidin et al, 2020). Berdasarkan hasil penelitian terdahulu dan beberapa teori pendukung, maka peneliti akan mengungkap persespsi siswi perempuan terhadap perilaku seks bebas.

\section{Metode}

Penelitiian ini merupakan jenis penelitian kuantitatif deskriptif (Plonsey, Barr, \& Bioelectricity, 2007) yang mengungkapkan dan mendeskripsikan persespsi siswi perempuan terhadap perilaku seks bebas. Populasi dalam penelitian ini yaitu seluruh siswa Sekolah Menengah Pertama Negeri 24 Kerinci dan peneliti mengggunakan teknik pengambilan sampel total sampling sehingga yang menjadi subjek penelitian ini yaitu siswi kelas VII dan VIII yang berjumlah 39 orang. Data dalam penelitian ini diungkap menggunakan skala Perilaku Seks Bebas yang telah di uji validtas dan reabilitasnya dengan nilai Cronbach's Alpha sebesar 0.86. Skala ini menggunakan 4 alternatif jawaban diantaranya Sangat Setuju diberi skor 4, Setuju diberi skor 3, Cukup Setuju diberi skor 2 dan Tidak Setuju diberi skor 1. Skala Perilaku Seks Bebas ini mengungkap aspek-aspek berikut: 1) pengetahuan, 2) sumber informasi, 3) pemahaman agama, 4) persepsi yang tidak baik, dan 5) peran keluarga. Data yang dikumpulkan selanjutnya ditabulasi untuk memudahkan proses analisis data. Analisis data menggunakan bantuan program SPSS 25.00 untuk dilakukan proses statistik deskriptif guna mengungkap persespsi siswi perempuan terhadap perilaku seks bebas. 


\section{Hasil dan Diskusi}

Sebanyak 39 orang siswi perempuan yang diolah datanya untuk mengungkap persepsi siswi perempuan tentang seks bebas. Hasil pengolahan skala perilaku seks bebas secara umum dapat dilihat pada tabel berikut:

Tabel 1. Distribusi Frekuensi Persepsi Siswi Perempuan Terhadap Perilaku Seks Bebas

\begin{tabular}{ccc}
\hline Kategori & Frekuensi & Persentase \\
\hline Buruk & 13 & 33,33 \\
Sedang & 12 & 30,77 \\
Baik & 14 & 35,90 \\
Jumlah & $\mathbf{3 9}$ & $\mathbf{1 0 0}$ \\
\hline
\end{tabular}

Dari tabel 1 dapat dilihat bahwa dari 39 orang siswi perempuan, terdapat sebanyak 13 orang siswi yang memiliki persepsi perilaku seks bebas merupakan hal yang biasa yaitu sebesar 33,33\%, kemudian sebanyak 12 orang siswi yang memiliki persepsi seks bebas merupakan boleh-boleh saja yaitu sebesar 30,70\%, seterusnya ada sekitar 14 orang siswi yang memiliki persepsi seks bebas merupakan sesuatu yang tidak boleh dilakukan yaitu sebesar 35,90\%.

Selanjutnya, hasil pengolahan skala perilaku seks bebas dilihat dari segi pengetahuan yang dimiliki siswi bisa dilihat pada tabel berikut:

Tabel 2. Distribusi Frekuensi Persepsi Siswi Perempuan Terhadap Perilaku Seks Bebas Dilihat dari Segi Pengetahuan

\begin{tabular}{ccc}
\hline Kategori & Frekuensi & Persentase \\
\hline Buruk & 11 & 28,21 \\
Sedang & 9 & 23,08 \\
Baik & 19 & 48,72 \\
Jumlah & $\mathbf{3 9}$ & $\mathbf{1 0 0}$ \\
\hline
\end{tabular}

Dari tabel 2 dapat dilihat bahwa dari 39 orang siswi perempuan, terdapat sebanyak 11 orang siswi yang memiliki pengetahuan tentang perilaku seks bebas dengan kategori buruk yaitu sebesar 28,21\%, kemudian sebanyak 9 orang siswi yang memiliki pengetahuan tentang perilaku seks bebas dengan katogori sedang yaitu sebesar 23,08\%, seterusnya ada sekitar 19 orang siswi yang memiliki pengetahuan tentang perilaku seks bebas dengan kategori baik yaitu sebesar 48,72\%.

Kemudian, hasil pengolahan skala perilaku seks bebas dilihat dari segi sumber informasi yang dicarai siswi bisa dilihat pada tabel berikut: 
Tabel 3. Distribusi Frekuensi Persepsi Siswi Perempuan Terhadap Perilaku Seks Bebas Dilihat dari Segi Sumber Informasi

\begin{tabular}{ccc}
\hline Kategori & Frekuensi & Persentase \\
\hline Buruk & 15 & 38,46 \\
Sedang & 8 & 20,51 \\
Baik & 16 & 41,03 \\
Jumlah & $\mathbf{3 9}$ & $\mathbf{1 0 0}$ \\
\hline
\end{tabular}

Dari tabel 3 dapat dilihat bahwa dari 39 orang siswi perempuan, terdapat sebanyak 15 orang siswi yang memiliki sumber informasi tentang perilaku seks bebas dengan kategori buruk yaitu sebesar $38,46 \%$, kemudian sebanyak 8 orang siswi yang memiliki sumber informasi tentang perilaku seks bebas dengan katogori sedang yaitu sebesar 20,51\%, seterusnya ada sekitar 16 orang siswi yang memiliki sumber informasi tentang perilaku seks bebas dengan kategori baik yaitu sebesar 41,03\%

Seterusnya, hasil pengolahan skala perilaku seks bebas dilihat dari segi pemahaman agama yang dimiliki siswi bisa dilihat pada tabel berikut.

Tabel 4. Distribusi Frekuensi Persepsi Siswi Perempuan Terhadap Perilaku Seks Bebas Dilihat dari Segi Pemahaman Agama

\begin{tabular}{ccc}
\hline Kategori & Frekuensi & Persentase \\
\hline Buruk & 8 & 20,51 \\
Sedang & 14 & 35,90 \\
Baik & 17 & 43,59 \\
Jumlah & $\mathbf{3 9}$ & $\mathbf{1 0 0}$ \\
\hline
\end{tabular}

Pada tabel 4 dapat dilihat bahwa dari 39 orang siswi perempuan, terdapat sebanyak 8 orang siswi yang memiliki pemahaman agama tentang perilaku seks bebas dengan kategori buruk yaitu sebesar 20,51\%, kemudian sebanyak 14 orang siswi yang memiliki pemahaman agama tentang perilaku seks bebas dengan katogori sedang yaitu sebesar 35,90\%, seterusnya ada sekitar 17 orang siswi yang memiliki pemahaman agama tentang perilaku seks bebas dengan kategori baik yaitu sebesar $43,59 \%$.

Lebih lanjut, hasil pengolahan skala perilaku seks bebas dilihat dari segi persepsi tidak baik yang dimiliki siswi bisa dilihat pada tabel berikut

Tabel 5. Distribusi Frekuensi Persepsi Siswi Perempuan Terhadap Perilaku Seks Bebas Dilihat dari Segi Persepsi yang Tidak Baik

\begin{tabular}{ccc}
\hline Kategori & Frekuensi & Persentase \\
\hline Buruk & 8 & 20,51 \\
Sedang & 15 & 38,46 \\
Baik & 16 & 41,03 \\
Jumlah & $\mathbf{3 9}$ & $\mathbf{1 0 0}$ \\
\hline
\end{tabular}


Pada tabel 5 dapat dilihat bahwa dari 39 orang siswi perempuan, terdapat sebanyak 8 orang siswi yang memiliki persepsi yang tidak baik tentang perilaku seks bebas dengan kategori buruk yaitu sebesar 20,51\%, kemudian sebanyak 15 orang siswi yang memiliki persepsi yang tidak baik tentang perilaku seks bebas dengan katogori sedang yaitu sebesar 38,46\%, seterusnya ada sekitar 16 orang siswi yang memiliki persepsi yang tidak baik tentang perilaku seks bebas dengan kategori baik yaitu sebesar $41,03 \%$.

Selanjutnya, hasil pengolahan skala perilaku seks bebas dilihat dari segi peran keluarga bisa dilihat pada tabel berikut

Tabel 6. Distribusi Frekuensi Persepsi Siswi Perempuan Terhadap Perilaku Seks Bebas Dilihat dari Segi Peran Keluarga

\begin{tabular}{ccc}
\hline Kategori & Frekuensi & Persentase \\
\hline Buruk & 12 & 30,77 \\
Sedang & 5 & 12,82 \\
Baik & 22 & 56,41 \\
Jumlah & $\mathbf{3 9}$ & $\mathbf{1 0 0}$ \\
\hline
\end{tabular}

Pada tabel 6 dapat dilihat bahwa dari 39 orang siswi perempuan, terdapat sebanyak 12 orang siswi yang memiliki peran keluarga dalam memahami perilaku seks bebas dengan kategori buruk yaitu sebesar 30,77\%, kemudian sebanyak 5 orang siswi yang memiliki peran keluarga dalam memahami perilaku seks bebas dengan katogori sedang yaitu sebesar $12,82 \%$, seterusnya ada sekitar 22 orang siswi yang memiliki peran keluarga dalam memahami perilaku seks bebas dengan kategori baik yaitu sebesar $56,413 \%$.

Dari paparan data di atas, secara umum persepsi siswi perempuan terhadap perilaku seks bebas di SMP N 24 Kerinci berada pada kategori baik dengan di temukannya jumlah persentase tertinggi yaitu 35,90\% sebanyak 14 orang. Persepsi siswi perempuam mengenai perilaku seks bebas dipandang sebagai sesuatu di larang atau berdosa, dari segi pengetahuan dan informasi siswi perempuan telah betul memahami tentang perlaku seks bebas, keluarga sangatlah penting dalam mengawasi pergaulan anaknya dan terbuka kepada orang tua salah satu terhiindar dari seks bebas.

Sesuai dengan hasil penelitian ini menunjukkan bahwa siswi perempuan memiliki persepsi pengetahuan yang baik, pemikiran mereka tentang seks bebas dan menunjang mereka untuk dapat membatasi diri agar tidak terjerumus pergaulan bebas (Susanti, Setyowati, \& Nanik, 2013). Seperti dijabarkan dalam angket item nomor 17, Seks bebas merupakan cara yang tepat untuk membuktikan rasa cinta, seharusnya untuk membuktikan rasa cinta harus dengan menikah, padahal logikanya apabila kita berbicara dari pandangan agama itu adalah zina dan dosa. Sesuai penelitian yang dilakukan Rohdi (Basit, 2017) menunjukan bahwa semakin tinggi sikap beragama seseorang maka akan semakin rendah kecenderungan perilaku seks bebas, begitu juga dengan sebaliknya semakin rendah sikap beragama seseorang maka akan semakin tinggi kecendrungan perilaku seks bebas seseorang, adanya berbagai informasi yang menyesatkan yang menimbulkan terjadinya salah persepsi tentang seks bebas serta munculnya rasa keingintahuan yang dalam terhadap masalah seks bebas dapat menyebabkan terjadinya hubungan seks bebas (Rasyidillah, 2017). 
Kemudian dari hasil penelitian Isnaini., Astiti, \& Paramita (2014) mengungkapkan bahwa terdapat perbedaan persepsi tentang seks pranikah dan sikap remaja putri yang pernah melakukan seks pranikah dan yang tidak melakukan seks pranikah. Kurangnya pengetahuan, informasi tentang seks serta persepsi remaja mengenai seluk beluk seks yang salah merupakan salah satu indikator meningkatnya perilaku seks bebas di kalangan remaja (Susilawati, Nilakesuma, \& Surya, 2019). Jadi dapat dikatakan siswa cerdas adalah siswa yang bisa menyaring pergaulanya dan membatasi agar tidak terjerumus dalam hal-hal yang tidak diingikan.

\section{Kesimpulan}

Kesimpulan secara umum dari penelitian ini terkait dengan persepsi siswi perempuan terhadap perilaku seks bebas di SMP N 24 Kerinci berada pada kategori baik. Kemudian persepsi siswi perempuan terhadap perilaku seks bebas dilihat dari segi pengetahuan berada pada kategori baik, selanjutnya persepsi siswi perempuan terhadap perilaku seks bebas dilihat dari segi sumber informasi berada pada kategori baik, seterusnya persepsi siswi perempuan terhadap perilaku seks bebas dilihat dari segi pemahaman agama berada pada kategori baik, kemudian persepsi siswi perempuan terhadap perilaku seks bebas dilihat dari segi persepsi yang tidak baik berada pada kategori baik dan persepsi siswi perempuan terhadap perilaku seks bebas dilihat dari segi peran keluarga berada pada kategori baik. Dari hasil penelitian ini, disarankan kepada peneliti selanjutnya untuk meneliti pada skala lebih besar sehingga bisa mendapat gambaran untuh dari siswi perempuan terkait dengan perilaku seks bebas.

\section{Ucapan Terima Kasih}

Ucapan terima kasih penulis sampaikan kepada dosen pembimbing Bapak Hengki Yandri, M.Pd., Kons., yang telah banyak membimbing dan memberikan masukan terhadap artikel ini. Kemudian kepada Ibu Dosi Juliawati, M.Pd., Kons., yang telah memberikan masukan terhadap artikel ini dan bersedia memvalidasi skala penelitian yang peneliti kembangkan. Seterusnya kepada Kepala Sekolah Menengah Pertama Negeri 24 Kerinci yang telah memberikan izin kepada peneliti untuk melakukan penelitian disana dan kepada seluruh responden penelitian yang telah bersedia meluangkan waktunya sehingga penelitian ini bisa diselesaikan dengan baik

\section{Referensi}

Aini, N. (2016). Pengaruh tipe kepribadian dan lingkungan pergaulan terhadap perilaku seksual remaja di SMP" XY" Swasta Kota Malang. Jurnal Ners dan Kebidanan Journal of Ners and Midwifery), 3(1), 070-078.

Al-Mighwar, M. (2011). Psikologi Remaja. Bandung: Pustaka Setia.

Astrini, D. (2007). Perbedaan Sikap Antara Remaja Laki-Laki dan Perempuan Terbadap Pornografi. (Skripsi, Universitas Sanata Dharma Yogyakarta)

Basit, A. (2017). Hubungan antara Perilaku Seksual dengan tingkat pengetahuan agama islam pada siswa sekolah menengah kejuruan (SMK). Jurnal Aisyah: Jurnal Ilmu Kesehatan, 2(2), 175-180.

Isnaini, U. N., Astiti, D., \& Paramita, D. P. (2014). Persepsi Tentang Seks Pranikah Pada Remaja Putri Yang Bertempat Tinggal di Kos dan di Rumah di Kasihan, Bantul. Jurnal Ners dan Kebidanan Indonesia, 2(3), 128-135. 
Istiqomah, N., \& Notobroto, H. B. (2016). Pengaruh Pengetahuan, Kontrol Diri Terhadap Perilaku Seksual Pranikah di Kalangan Remaja SMK di Surabaya. Jurnal Biometrika dan Kependudukan, 5(2), 125-134.

Kholidin, F. I., Putri, E. E., Yandri, H., Juliwati, D., \& Erniyati, Y. (2020). The analysis of student's junior high school perception of free sex behavior in terms of gender differences. KONSELI: Jurnal Bimbingan dan Konseling (E-Journal), 7(2), 123-128.

Marliany. (2010). Psikologi Umum. Bandung: Pustaka Setia.

Novitasari, D. W., Nikmah, L., \& Sulistyoningtyas, S. (2017). Persepsi remaja kelas XI terhadap perilaku seks bebas di SMK Muhammadiyah 1 Moyudan Kabupaten Sleman Yogyakarta. (Skripsi, Universitas Asyiyah Yogyakarta).

Plonsey, R., Barr, R. C., \& Bioelectricity, A. (2007). Quantitative Approach. New York, NY: Springer.

Rasyidillah, A. (2017). Persepsi Remaja Tentang Perilaku Seks Pranikah (Studi pada Remaja di Kota Tangerang) (Skripsi, FITK UIN Syarif Hidayatullah Jakarta).

Sari, I. K. (2011). Persepsi Remaja Terbadapa Dimensi Seksualitas Hubungan Seks Bebas pada Siswa SMA Negeri 10 Makassar (Skripsi, Universitas Islam Negeri Alauddin Makassar).

Sartika, M., \& Yandri, H. (2019). Pengaruh layanan bimbingan kelompok terhadap konformitas teman sebaya. Indonesian Journal of Counseling and Development, 1(1), 9-17.

Situmorang, K., \& Sanusi, S. R. (2016). Hubungan Pendidikan Seks oleh Orang Tua dengan Perilaku Seksual Remaja di SMA Al-Maksum Desa Cinta Rakyat Kecamatan Percut Sei Tuan Kabupaten Deli Serdang. (Skripsi, Universitas Sumatera Utara)

Sugiyatno. (2016). Standar Kompetensi Kemandirian (SKK). Universitas Negeri Yogyakarta. Diakses di http://staffnew.uny.ac.id/upload/132296044/pendidikan/materi-kuliah-dasar-dasar-bk2.pdf

Sumiatin, T., Purwanto, H., \& Ningsih, W. T. (2017). Pengaruh Persepsi Remaja Tentang Perilaku Seks Terhadap Niat Remaja Dalam Melakukan Perilaku Seks Berisiko. Jurnal Keperawatan, 8(1), 96-101.

Susanti, S., Setyowati, E., \& Nanik, R. (2013). Persepsi Siswa Kelas XI SMK Negeri 4 Surabaya terhadap Perilaku Seks Bebas dikalangan Pelajar Surabaya. IPI, 3(1), 2.

Susilawati, D., Nilakesuma, N. F., \& Surya, D. O. (2019). Penyuluhan kesehatan reproduksi remaja di SMP Pertiwi Siteba Padang. Jurnal Kreativitas Pengabdian Kepada Masyarakat (PKM), 2(2), 171 176.

Taufik, A. (2013). Persepsi Remaja Terhadap Perilaku Seks Pranikah (Studi Kasus SMK Negeri 5 Samarinda). Ejournal sosiatri-sosiologi, 1(1), 31-44.

Wahareni, P. A. (2006). Sikap remaja terbadap perilaku seks bebas ditinjau dari tingkat penalaran moral pada siswa kelas dua SMA Kesatrian 1 Semarang. (Skripsi. Universitas Negeri Semarang)

Yandri, H., \& Juliawati, D. (2018). Profile of the problem of the adolescent with parents as Indonesian migrant workers. Konselor, 7(4), 160-165. 